tion in adult sheep and ontogeny in the sheep fetus. Intern. Arch. Allergy Appl. Immunol., 49: 658 (1975)

28. Taylor, S. and Bryson, Y. V.: Impaired production of immune (PHA-induced) interferon in newborns is due to a functionally immature macrophage. Pediatr. Res. (abstract), 15: 604 (1981).

29. Wu, S., Bach, F. H., and Auerbach, R.: Cell-mediated immunity: differential maturation of mixed leucocyte reaction and cell mediated lympholysis. $\mathbf{J}$. Exp. Med., 142: 1301 (1975).

30. Wybran, L., Carr, M. C., and Fudenberg, H. H.: Effect of serum on human rosette forming cells in fetuses and adult blood. Clin. Immunol. Immunopathoi., $1: 408$, (1973).

31. Requests for reprints should be addressed to: Dr. Rukmani Raghunathan, Dept. of Pediatrics, UCLA School of Medicine, Harbor-UCLA 100 W. Carson St., Torrance, CA 90509.

32. This research was supported by NICHD Progam Project 1-PO1 HD10975$04 \mathrm{~A} 1$.

33. Received for publication November $16,1982$.

34. Accepted for publication July 14,1982 .

\title{
Circadian Rhythms of Blood Minerals during Adolescence $^{(41)}$
}

\author{
MORRI E. MARKOWITZ, ${ }^{(40)}$ JOHN F. ROSEN, SWAMY LAXMINARAYAN, AND \\ MARK MIZRUCHI \\ Department of Pediatrics, Clinical Research Center, Computer Center, Albert Einstein College of Medicine, \\ Montefiore Medical Center, Bronx, New York and Computer Center, New Jersey College of Medicine, \\ Newark, New Jersey, USA
}

\begin{abstract}
Summary
Sequential blood sampling every 30 min was performed in six adolescent males. Samples were analyzed for serum phosphate $\left(\left(P_{i}\right)\right.$, total calcium $\left(\mathbf{C a}_{T}\right)$, and blood ionized calcium $\left(\mathbf{C a}^{++}\right)$ concentrations. A circadian (24-h) pattern was observed for each mineral: 1) $\mathrm{Ca}^{++}$concentrations followed a $\mathrm{U}$-shaped curve with a peak at $11 \mathrm{AM}$ and a trough at 3:30 PM; 2) Ca concentrations followed a W-shaped curve with maxima at 11 and $1 \mathrm{AM}$ and troughs at $5 \mathrm{AM}$ and $6 \mathrm{PM}$; and 3) $\mathrm{P}_{\mathrm{i}}$ concentrations followed an M-shaped curve with peaks at $4 \mathrm{PM}$ and 3:30 AM. The overall mineral patterns were similar in shape to those previously decribed in adult males. In contrast, however, the amplitude of the $P_{i}$ fluctuations were considerably greater in the adolescents compared with that in adults $(3.0 \mathrm{mg} / \mathrm{dl}$ versus $1.2 \mathrm{mg} / \mathrm{dl})$. The $\mathrm{Ca}^{++}$pattern diverged from the $\mathrm{Ca}_{\mathrm{T}}$ pattern during the nocturnal phase to an extent that neither pattern could be predicted from the other. Ultradian rhythms were found in some of the time series mineral data sets; however, no single frequency encompassed all subjects for each circulating mineral.
\end{abstract}

Several hormones and minerals undergo daily rhythmic variations in their circulating concentrations $(4,6,22,32)$. Disturbances in these rhythms are manifestations of specific disease states $(5,28)$. Determination of normal rhythms aids in understanding physiologic processes and provides a rational basis for interpretation of laboratory data and possible therapeutic intervention.

In a recent investigation, we found that the 24-h pattern of blood ionized calcium $\left(\mathrm{Ca}^{++}\right)$concentrations in human males can be described by a U-shaped curve with a peak at 9:30-10:00 AM and a trough at 6:00-7:00 PM (18). The circadian (24-h) rhythm of serum phosphate $\left(\mathrm{P}_{\mathrm{i}}\right)$ concentrations was described by a curve with major and minor peaks at $2 \mathrm{AM}$ and $4 \mathrm{PM}$, respectively (18). The $P_{i}$ pattern was not predictable from changes in $\mathrm{Ca}^{++}$. Serum total calcium $\left(\mathrm{Ca}_{\Upsilon}\right)$ concentrations fluctuated inversely with $\mathrm{P}_{\mathrm{i}}$ and also could not be predicted consistenly from changes in $\mathrm{Ca}^{++}$concentrations (18). Other studies have found nocturnal elevation in serum $\mathrm{P}_{\mathrm{i}}$ concentration, and either a nocturnal fall or no diurnal variation in $\mathrm{Ca}_{\mathrm{T}}$ concentrations ( 7 , $15,17,30,33)$. To date, one other study of $24-\mathrm{h} \mathrm{Ca}^{++}$concentrations was performed in postmenopausal women (25). These authors reported a similar but phase-shifted $\mathrm{Ca}^{++}$pattern.

Several hormones progress through a pubertal-stage-associated maturation in their 24-h patterns (32). To determine whether ontogeny occurs during the development of blood mineral rhythms, we extended our studies to a group of six healthy male teenagers. Adolescence was chosen because this period is one of increased bone re-cycling rates, thereby maximizing (perhaps) the likelihood of finding mineral patterns different from those in adults (2). The study was limited to males in order to avoid the confounding effects of sex hormone fluctuations that occur during the menstrual cycle $(27,31)$. We found mineral patterns that were similar in shape and duration to those in adults; however, the amplitude in the daily phosphate fluctuations was considerably greater in teenagers, compared with that in adults.

\section{MATERIALS AND METHODS}

Subjects. Six healthy adolescent males, aged 13-17 yr and Tanner 4 and 5, participated in this study after informed consent was obtained from both parents and subjects. None had any history of recent fractures, immobilization, endocrine, bone, renal or liver disease, increased mineral or vitamin D intake, or drug use. All had nocturnal sleeping habits. Pre-study physical examinations were normal.

Protocol. Pairs of teenagers were admitted to the Clinical Research Center on the night before the study to adapt to the facilities. These consisted of a two-room suite with toilet. A technician remained in the outer chamber throughout the study and was responsible for blood sampling, event logging, and EEG recordings to confirm sleep time. The subjects had proscribed daytime activities and were not allowed to sleep. Lights out occurred at midnight. A fixed diet-consisting of approximately $400 \mathrm{mg}$ calcium, $900 \mathrm{mg}$ phosphate, and $200 \mathrm{IU}$ of vitamin Dwas divided into three meals given at 8:30 AM, 12 noon, and 5:30 PM.

On the morning after admission, an indwelling venous catheter was placed in an anticubital vein. To maintain catheter patency 
for blood sampling every $30 \mathrm{~min}$, a solution containing $5 \%$ dextrose, $1 / 4$ normal saline, and $5000 \mathrm{U}$ heparin (34) per liter was infused by IMED pump (35) through Deseret 12-ft extension tubing at $5 \mathrm{ml} / \mathrm{h}(36)$. Blood was sampled in a four-stopcock system in which intravenous fluid and diluted blood are first drawn into the distal (to subject) clearing-syringe to the 8-ml mark. The dead space of the tubing is less than $3 \mathrm{ml}$. Samples are then taken in the proximal sample-syringe. After sampling for serum $\mathrm{Ca}_{\mathrm{T}}$ and $\mathrm{P}_{\mathrm{i}}$ (the first sample), the syringe is replaced by a second $3-\mathrm{ml}$ syringe (containing $75 \mu \mathrm{l}$ of heparin, $1000 \mathrm{U} /$ ml) into which $1.5 \mathrm{ml}$ of blood are drawn anaerobically for $\mathrm{Ca}^{++}$ measurements (18). After sampling, the contents of the clearingsyringe are returned to the subject and residual blood is flushed out of the line with a $5 \%$ dextrose, $1 / 4$ normal saline solution without heparin. Generally, $5 \mathrm{ml}$ were required for flushing. Finally, an additional $3 \mathrm{ml}$ of the maintenance solution was infused by pump to reinstill a heparinized solution to the catheter tip. An average of $300 \mathrm{ml}$ of the heparinized solution was infused over $24 \mathrm{~h}$, containing a total of $1500 \mathrm{U}$ of heparin. An average of $325 \mathrm{ml}$ (<10\% calculated blood volume of each subject) was removed over the study period of $24 \mathrm{~h}$.

The sample for serum $\mathrm{Ca}_{\mathrm{T}}$ and $\mathrm{P}_{\mathrm{i}}$ was allowed to stand in a vacutainer tube for $1-2 \mathrm{~h}$ until clotting was complete. It was then centrifuged and the obtained serum was frozen for latter analysis. $\mathrm{Ca}_{\mathrm{r}}$ was measured by atomic absorption spectrophotometry (37) and serum $P_{i}$ by an autoanalyzer (38). The $\mathrm{Ca}^{++}$ samples were immediately capped air tight, mixed by hand for $30 \mathrm{sec}$, and placed in shaved ice for $1 \mathrm{~h}$. They were then run in triplicate on a Nova II calcium ion analyzer (39). The first run was used to prime the membrane, and the value was discarded. The mean of the second and third runs was used as the $\mathrm{Ca}^{++}$ value for that time point. Variabilities $( \pm 3 \mathrm{SE})$ for duplicate measurements of $\mathrm{Ca}^{++}, \mathrm{Ca}_{\Upsilon}$, and $\mathrm{P}_{\mathrm{i}}$ were $0.05,0.18$, and 0.08 $\mathrm{mg} / \mathrm{dl}$, respectively $(18)$. These values were obtained by an analysis of variance for duplicate measurements. At the initiation of the study, blood for determination of $1,25-(\mathrm{OH})_{2} \mathrm{D}, 25-\mathrm{OH}$ vitamin $\mathrm{D}$, and PTH concentrations was drawn and measured by techniques described elsewhere $(1,9,29)$.

Statistics. Two forms of statistical analyses were performed. In the first, mineral data at each of the 48 time points were averaged across all subjects. These data were then smoothed (when necessary) by using the technique of running medians (18). This eliminated minor fluctuations in the raw mean data. The data were then fitted by a polynomial regression of the variable $\left(\mathrm{Ca}^{++}, \mathrm{Ca}\right.$, or $\left.\mathrm{P}_{\mathrm{i}}\right)$ against time to yield the three mineral models (18). These are somewhat idealized mathematical representations of the 24-h data. Regression analysis and $r \rightarrow z$ transformation of each teenager's data against the model were performed in order to ascertain how well each subject's data set was described by the particular model and whether there were any outliers.

The second statistical method, spectral analysis (Fourier analysis, periodogram method) treats each subject's data set as unique time series data. No assumption that the subject's rhythms are synchronized with each other is made, as is the case in the first type of analysis. In addition, the minor fluctuations in the raw data are considered as potentially reflecting biologically significant events rather than "background noise." The method determines whether these fluctuations occur rhythmically at frequencies of $<24 \mathrm{~h}$ (ultradian). In this form of spectral analysis, the data are transformed into a series of sine waves of varying frequencies and amplitudes (3). Each raw mineral data set from each subject so studied yields a spectral graph. The spectral data are then subjected to Hanning, a smoothing technique. Fisher's tests of significance are then applied to the observable peaks to determine which frequencies or periodicities are statistically significant (3).

\section{RESULTS}

The mean mineral concentrations throughout the study as well as the baseline determinations of 25-hydroxyvitamin D, 1,25$(\mathrm{OH})_{2} \mathrm{D}$, and PTH levels were normal in all the adolescents (Table 1).

The data from all subjects for each mineral are plotted in Figure 1. Observations at each of the 48 time points were then averaged across all individuals to yield Figures $2 \mathrm{a}, 3 \mathrm{a}$, and $4 \mathrm{a}$. A partial exception to this is Figure $2 a$. Inspection of the individual $\mathrm{Ca}^{++}$raw data (Fig. 1) curves suggested that two of the subjects (IB and JI) had $\mathrm{Ca}^{++}$patterns that were phase-shifted to the right on the time axis i.e., delayed $1 \frac{1}{2} \mathrm{~h}$. Therefore, the $\mathrm{Ca}^{++}$data from these subjects were withheld during the analysis of the general $\mathrm{Ca}^{++}$pattern. They were included, however, in the linear regression analysis of raw data versus model curves presented in Table 2 .

The mean data for each mineral were then smoothed to yield Figures $2 \mathrm{~b}, 3 \mathrm{~b}$, and $4 \mathrm{~b}$. Finally the data were fitted by polynomial regression of the variable against time resulting in the models (Figs. 2c, 3c, and 4c). The correlations between the raw mean data and the three models were the following: $r_{\mathrm{Ca}^{++}}=0.93, r_{\mathrm{Car}_{\mathrm{r}}}$ $=0.85$, and $r_{\mathrm{P}_{\mathrm{i}}}=0.97,(P<0.001)$. Intermodel correlations were the following: $r_{\mathrm{Ca}^{++} / \mathrm{Ca}_{\mathrm{T}}}=0.43(P<0.05), r_{\mathrm{Ca}^{++} / \mathrm{P}_{\mathrm{i}}}=0.18(P>$ $0.05)$ and $r_{\mathrm{Ca}_{\mathrm{T}} / \mathrm{P}_{\mathrm{i}}}=-0.81(P<0.01)$. The $\mathrm{Ca}^{++}$and $\mathrm{Ca}_{\mathrm{r}}$ patterns are readily distinguishable from each other. The $\mathrm{Ca}^{++}$and $\mathrm{P}_{\mathrm{i}}$ patterns are not predictable inverse reflections of each other. These results are similar to those observed in young adult males (18). The $P_{i}$ concentration underwent wide daily fluctuations in amplitude with a peak-trough difference of $3.0 \mathrm{mg} / \mathrm{dl}$, considerably greater fluctuations than the peak-trough difference found in adult male subjects. Each individual subject's data were regressed against the appropriate model. This was followed by $r \rightarrow$ $\mathrm{z}$ transformation to determine outliers (Table 2). No outliers were found.

Sufficient numbers of time point measurements were available from $5 / 6$ subjects to carry out spectral analyses of the time series. Ultradian frequenies varying between $1.2-11.8 \mathrm{~h}$ were found (Table 3). The most commonly observed $\mathrm{Ca}^{++}$periodicities were $1.2-3.9 \mathrm{~h}$ ( $3 / 5$ and $2 / 5$ subjects, respectively); $\mathrm{Ca}_{\mathrm{T}}$ periodicities of $1.2-1.3$ and $11.8 \mathrm{~h}(2 / 5$ and $3 / 5$ subjects, respectively) were observed. With the exception of subject 5 (a 19.5-h study) no

Table 1. Anthropometric and mean or baseline biochemical data*

\begin{tabular}{|c|c|c|c|c|c|c|c|c|c|c|}
\hline & Age & $\begin{array}{l}\text { Weight } \\
(\mathrm{kg})\end{array}$ & $\begin{array}{l}\text { Height } \\
(\mathrm{cm})\end{array}$ & $\begin{array}{l}\text { Blood } \\
\text { volume } \\
\text { removed } \\
(\mathrm{ml})\end{array}$ & $\begin{array}{c}\mathrm{Ca}^{++} \\
(\mathrm{mg} / \mathrm{dl} \pm \mathrm{SD})\end{array}$ & $\begin{array}{c}\mathrm{Ca} a_{r} \\
(\mathrm{mg} / \mathrm{dl} \pm \mathrm{SD})\end{array}$ & $\begin{array}{c}\mathrm{P}_{\mathrm{i}} \\
(\mathrm{mg} / \mathrm{dl} \pm \mathrm{SD})\end{array}$ & $\begin{array}{c}\text { PTH } \\
(\mu \mathrm{leq} / \mathrm{ml})\end{array}$ & $\begin{array}{c}25-\mathrm{OHD} \\
(\mathrm{ng} / \mathrm{ml})\end{array}$ & $\begin{array}{c}1,25-(\mathrm{OH})_{2} \mathrm{D} \\
(\mathrm{pg} / \mathrm{ml})\end{array}$ \\
\hline \multicolumn{11}{|c|}{ (lol } \\
\hline IB & $17 \mathrm{yr}, 6 \mathrm{mo}$ & 75.5 & 174 & 439 & $4.59 \pm 0.12$ & $9.0 \pm 0.2$ & $4.0 \pm 0.4$ & 14 & 42 & 60 \\
\hline DY & $15 \mathrm{yr}, 5 \mathrm{mo}$ & 45.9 & 154 & 228 & $4.62 \pm 0.17$ & $9.2 \pm 0.6$ & $5.3 \pm 0.6$ & 11 & 29 & 40 \\
\hline JI & $15 \mathrm{yr}, 11 \mathrm{mo}$ & 55.5 & 163 & 252 & $4.49 \pm 0.17$ & $9.0 \pm 0.3$ & $4.3 \pm 0.8$ & $\ldots$ & 37 & 50 \\
\hline $\mathrm{JM}$ & $14 \mathrm{yr}, 6 \mathrm{mo}$ & 54.0 & 163 & 276 & $4.61 \pm 0.12$ & $9.1 \pm 0.3$ & $4.8 \pm 0.9$ & 21 & 31 & 54 \\
\hline $\mathrm{CR}$ & $14 \mathrm{yr}, 6 \mathrm{mo}$ & 68.9 & 167 & 319 & $4.48 \pm 0.22$ & $9.4 \pm 0.2$ & $5.2 \pm 0.8$ & 22 & 41 & 45 \\
\hline $\mathrm{DR}$ & $15 \mathrm{yr}, 1 \mathrm{mo}$ & 76.5 & 174 & 444 & $4.34 \pm 0.13$ & $9.0 \pm 0.2$ & $4.6 \pm 0.9$ & 18 & 39 & 48 \\
\hline Normal & & & & & $4.68 \pm 0.18$ & $9.7 \pm 0.2$ & $4.6 \pm 0.3$ & $<40$ & $31 \pm 10$ & $49 \pm 7$ \\
\hline
\end{tabular}

* Abbreviations: PTH, parathyroid hormone; 25-OHD, 25-hydroxyvitamin $\mathrm{D} ; 1$, 25- $(\mathrm{OH})_{2} \mathrm{D}, 1,25$-dihydroxyvitamin $\mathrm{D}$. 

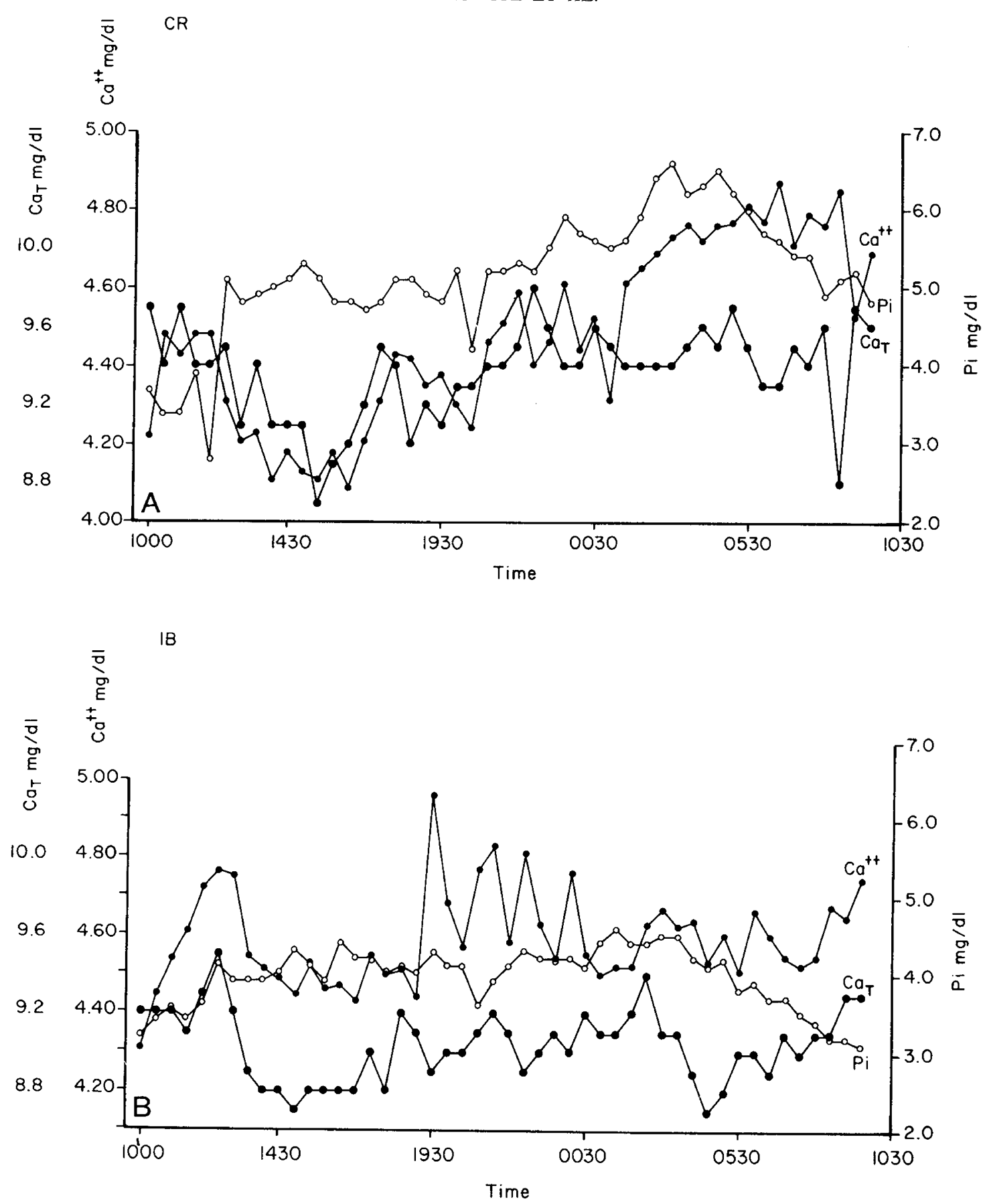

Fig. 1. Sequential blood sampling occurred every $30 \mathrm{~min}$ for $24 \mathrm{~h}$, beginning at $1000 \mathrm{~h}$. Open circles represent actual serum $\mathrm{P}_{\mathrm{i}}$ concentrations from each time point. Small closed circles represent $\mathrm{Ca}^{++}$and large closed circles represent $\mathrm{Ca}_{\mathrm{T}}$ concentrations. Figure $1 A$ is an example of a subject $(\mathrm{CR})$ whose patterns fit the three models well. Figure $\mathrm{I} B$ shows data from subject $\mathrm{IB}$ whose $\mathrm{Ca}^{++}$pattern had the lowest $\mathrm{Z}$ score (Table 2 ).

overlapping rhythms between $\mathrm{Ca}^{++}$and $\mathrm{Ca}_{T}$ were found. Furthermore, no consistent $P_{i}$ periodicity (ultradian) was observed.

Comparison between the teenage and adult rhythms was then performed by regression analysis of the two sets of mineral models. Significant correlations were observed for all three minerals: $r_{\mathrm{Ca}^{++}}=0.87, r_{\mathrm{Ca}_{\mathrm{T}}}=0.53, r_{\mathrm{P}_{\mathrm{i}}}=0.95,(P<0.01)$. Closer examination of the patterns revealed that, although the overall patterns were similar in shape and timing, the amplitudes of the $P_{i}$ changes were more than twice as large in the teens (Fig. 5).

\section{DISCUSSION}

This study indicates the presence of circadian and ultradian fluctuations in the concentrations of blood $\mathrm{Ca}^{++}$, serum $\mathrm{Ca}_{\mathrm{T}}$ and serum $P_{i}$ in adolescent males. The circadian patterns are similar in shape and phase relationship to those described previously in adult males (18). The amplitude of the diurnal $P_{i}$ variations were greater in the teenagers than the adults: 3.0 versus $1.2 \mathrm{mg} \cdot \mathrm{dl}^{-1}$. $\mathrm{d}^{-1}$. Tanner developmental staging did not discriminate between adolescent and adult amplitude variations.

To account for the wide excursions in $\mathrm{P}_{\mathrm{i}}$ concentrations, factors regulating serum $\mathrm{P}_{\mathrm{i}}$ concentration need to be identified to determine which, if any, also undergo alterations during adolescence. These include diet, various hormones and mineral interactions. Jubiz et al. have shown that the most powerful effects on circadian $P_{i}$ rhythms are produced by dietary manipulation. The pattern can be obliterated by fasting (17); however, the teenagers in this study received a diet similar in content and meal times to that in our previous study of adults (18). It appears that diet alone does not account for the modulation of the circadian $P_{i}$ pattern in adolescents.

The serum concentration of $1,25-(\mathrm{OH})_{2} \mathrm{D}$, one of the major 

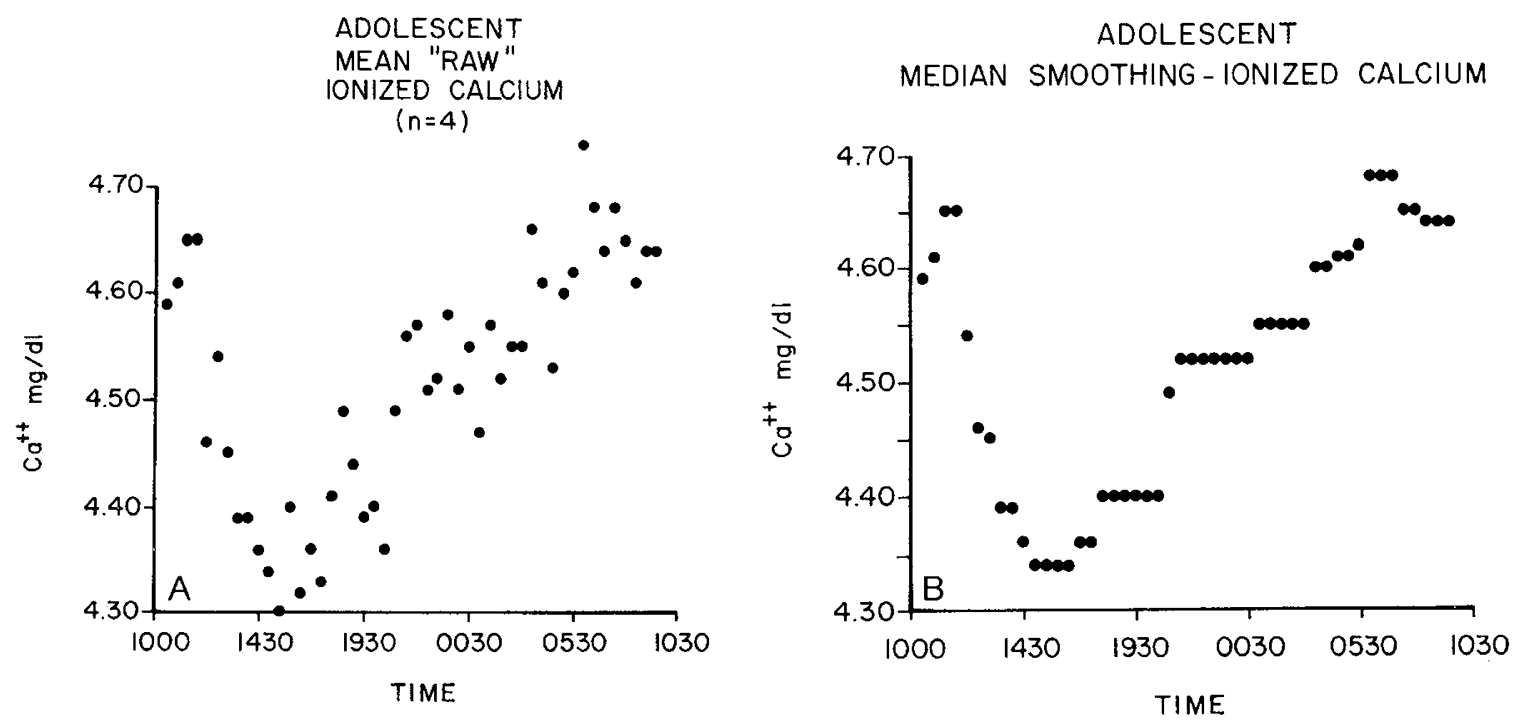

ADOLESCENT

IONIZED CALCIUM MODEL

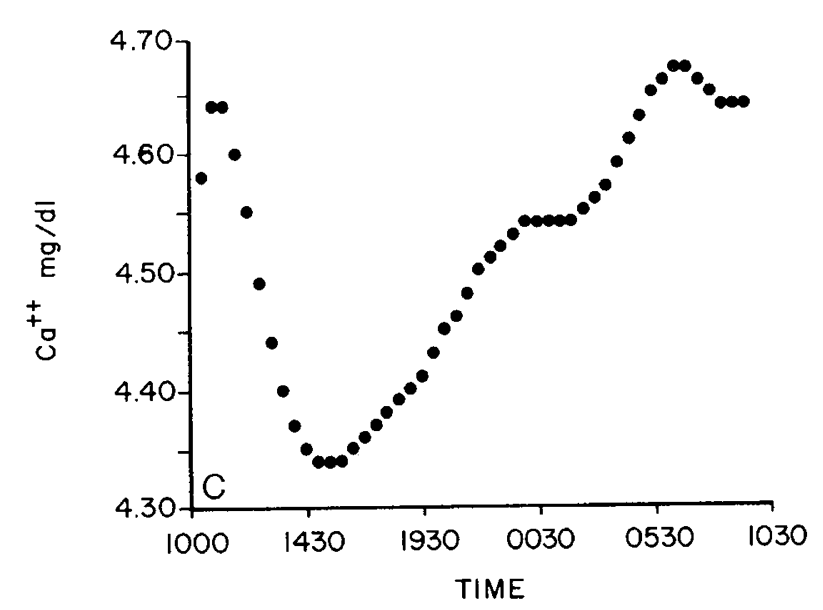
(C).

Fig. 2. Mean $\mathrm{Ca}^{++}$samples across all subjects at each time point $(A)$ were subjected to median smoothing $(B)$ and mathematical representation

calcium-regulating hormones, is increased during adolescence (8). We have noted also that $24-\mathrm{h}$ mean PTH concentrations were greater in a group of teenage males compared with adults (20). These findings are consistent with the increase in bone mineral turnover that occurs in adolescents (2). Neither finding fully accounts for the $\mathrm{P}_{\mathrm{i}}$ pattern because suppression of PTH by calcium infusion and, hence, $1,25-(\mathrm{OH})_{2} \mathrm{D}$ biogenesis, does not abolish the $P_{i}$ pattern (17).

Other hormones have been implicated in the regulation of $P_{i}$ metabolism such as growth hormone, thyroid hormone, insulin, glucagon, and cortisol (26). Of these, $(\mathrm{GH})$, acting possibly through its intermediary, somatomedin-C has an established relationship to serum $\mathrm{P}_{\mathrm{i}}$ i.e., acromegaly is associated with hyperphosphatemia. GH deficiency and subsequent replacement therapy results in increasing serum $P_{i}$ levels $(10,11,14,23) . G H$ and somatomedin- $\mathrm{C}$ concentrations are elevated in adolescents $(13,16)$. As with PTH, however, GH probably does not account for the shape of the $P_{i}$ curve (though it may contribute to the increase in amplitude) because the $P_{i}$ pattern is maintained in hypopituitarism (17).

Calcium ion is thought to exert a direct influence on renal $P_{i}$ handling independent of hormonal intermediaries such as PTH or $1,25-(\mathrm{OH})_{2} \mathrm{D}_{3}(24)$. Correction of hypocalcemia by Ca infusion in hypoparathyroid subjects results in increasing phosphaturia and diminishing serum phosphate (12). If the $24-\mathrm{h} \mathrm{Ca}^{++}$pattern observed in healthy subjects was responsible for the serum $P_{i}$ fluctuations, reciprocal changes in $\mathrm{Ca}^{++}$should have been observed. Furthermore, the amplitude of the $\mathrm{Ca}^{++}$changes might also have been altered during adolescence. Neither was the case. The $24-\mathrm{h} \mathrm{Ca}{ }^{++} / \mathrm{P}_{\mathrm{i}}$ correlation coefficient is not significant; both the amplitude and $24-\mathrm{h}$ pattern of $\mathrm{Ca}^{++}$are similar in the adolescents and in the adults. It is unlikely that $\mathrm{Ca}^{++}$is responsible for the $\mathrm{P}_{\mathrm{i}}$ changes.

An inverse correlation between $\mathrm{Ca}_{\mathrm{T}}$ and $\mathrm{P}_{\mathrm{i}}$ was observed $(r=$ $-.81)$. The physiologic importance of this statistically significant correlation remains unclear because the patterns can be dissociated by manipulations such as $\mathrm{Ca}$ infusion or fasting $(12,17)$. The $\mathrm{Ca}_{\mathrm{r}}$ pattern appears to reflect alterations in serum albumin $(17,18)$. Manuevers, such as bed rest for $24 \mathrm{~h}$ (thereby diminishing changes in vascular volume) flatten the nocturnal depression in both serum albumin and $\mathrm{Ca}_{\mathrm{T}}$ but do not affect the $\mathrm{P}_{\mathrm{i}}$ rise (17). Although serum albumin was not monitored sequentially, our subjects were out of bed and upright during the daytime in a regimen similar to that in our previously studied adults (18). In the latter group, a nocturnal fall in albumin was found, and this correlated significantly with changes in $\mathrm{Ca}_{\mathrm{T}}$ (18). We suggest, therefore, that the $\mathrm{Ca}_{\mathrm{T}}$ pattern is dependent on hemodynamic alterations in the concentration of serum albumin and not in response to hormonal regulation of $\mathrm{Ca}_{\mathrm{T}}$ itself.

Though the models provide excellent fits of the raw or 


$$
\begin{aligned}
& \text { ADOLESCENT } \\
& \text { MEAN "RAW" } \\
& \text { TOTAL CALCIUM } \\
& (n=6)
\end{aligned}
$$

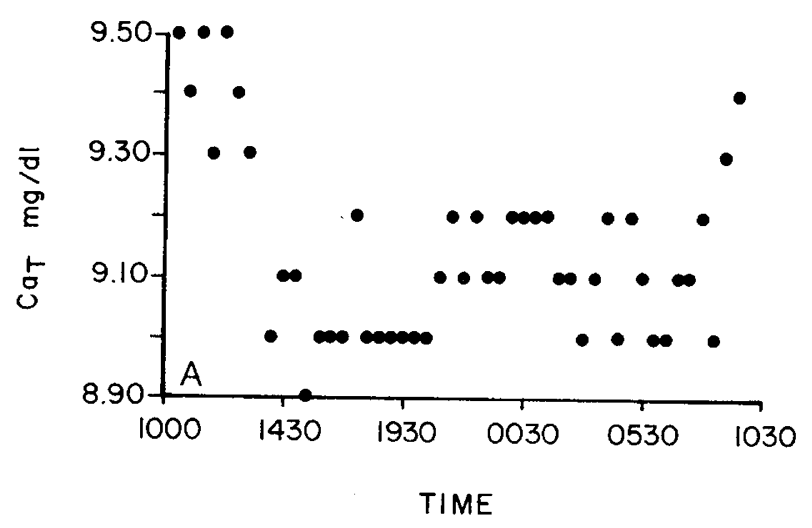

\author{
ADOLESCENT \\ MEDIAN SMOOTHING \\ TOTAL CALCIUM
}
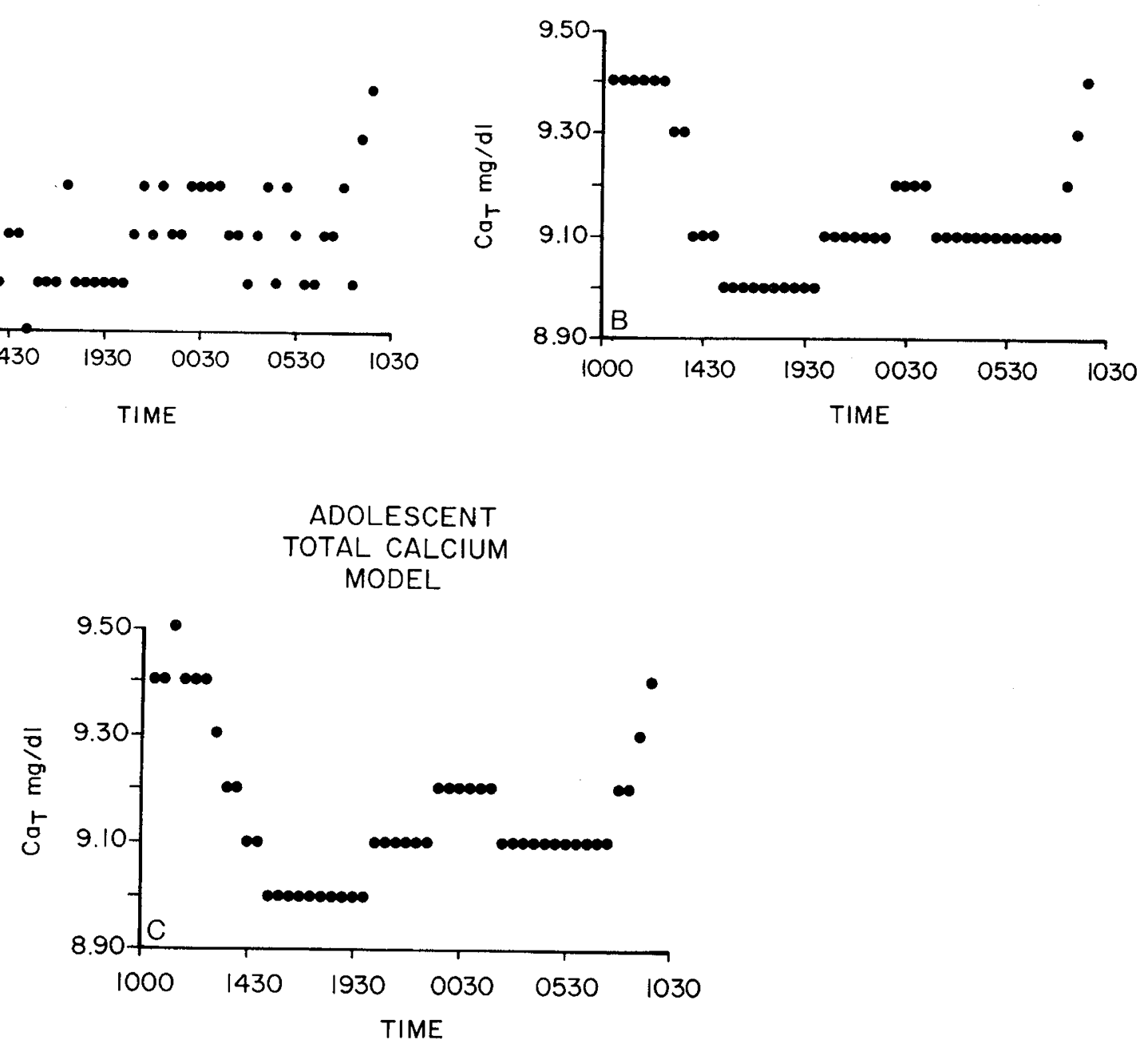

Fig. 3. As in Figure 2, Mean $\mathrm{Ca}_{\mathrm{T}}$ samples across all subjects at each time point $(A)$ were subjected to median smoothing $(B)$ and mathematical representation $(C)$.

smoothed mean data to the polynomial equations, individual subjects may not follow the "classic" pattern as closely. Individual subject's data sets may differ from the models either in pattern shape, amplitude of fluctuations, or phase relationships. By using correlation coefficients and $\mathrm{r} \rightarrow \mathrm{z}$ transformations, we found that $\mathrm{Ca}^{++}$patterns of two subjects (IB, JM) were not significantly related to the $\mathrm{Ca}^{++}$model $(P>0.05)$. Nevertheless, neither was an outlier. This reflects the wide range in $r$ values among the individuals comprising the normative $\mathrm{Ca}^{++}$model. Phrased differently, these subjects yielded relatively heterogeneous patterns for $\mathrm{Ca}^{++}$and $\mathrm{Ca}_{\mathrm{T}}$ and more homogeneous rhythms for serum $P_{i}$.

Two of the subjects (IB, JI) had discernable phase-shifts in $\mathrm{Ca}^{++}$patterns of about $1.5 \mathrm{~h}$. When this time lag is accounted for, the individual $r$ scores improve slightly $(r=0.21$ and 0.52 , respectively). Similarly, subject JM's $\mathrm{Ca}^{++}$pattern was phaseshifted by $1 \mathrm{hr}$. By eliminating this lag time, the correlation to the model improved $(0.21$ vs $0.25,0.05<P<0.1)$.

The method of defining circadian rhythms of blood minerals (so far discussed) assumes that the subject's patterns were synchronized, possibly by exogenous pacemakers such as the light/ dark cycle, sleep/wake cycle, meal times, and activity. Although environmental cues were controlled within the context of a Clinical Research Center setting, several subjects had phaseshifted $\mathrm{Ca}^{++}$patterns. If mean data are then derived from all subjects at concurrent time points, the amplitude of the plotted curve may be artifactually dampened. Spectral analysis offers an alternative method of data analysis. Because each data set is considered individually, lack of synchrony is no longer a consideration. In addition, ultradian frequencies may appear which otherwise would have been obscured. By the periodogram method of spectral analysis, high frequency oscillations in the $\mathrm{Ca}^{++}$data were found in three of the subjects (71-73-min cycle); these oscillations did not overlap with fluctuations in $P_{i}$. Furthermore, little overlap in ultradian frequencies was seen between $\mathrm{Ca}^{++}$and $\mathrm{Ca}_{\mathrm{T}}$ or between $\mathrm{Ca}_{\mathrm{T}}$ and $\mathrm{P}_{\mathrm{i}}$. This supports further the likelihood that these mineral patterns are subject, in part, to independent regulation.

The physiologic significance of the circadian and ultradian rhythms have only begun to be explored. Previously, we have shown that the $24 \mathrm{~h} \mathrm{Ca}^{++}$rhythm in hypoparathyroid children [receiving oral $1,25-(\mathrm{OH})_{2} \mathrm{D}_{3}$ treatment] may depend on the dose administration schedule; split daily doses, but not single daily doses, of the vitamin-D hormone were associated with normal $\mathrm{Ca}^{++}$patterns (19). In a different clinical context, children with chronic renal failure may develop deviations in their mineral patterns before any abnormalities in blood mineral concentrations in randomly drawn samples are documented (21).

In conclusion, adolescents (like adults) undergo daily rhythmic fluctuations in their blood mineral concentrations. Interpretation 

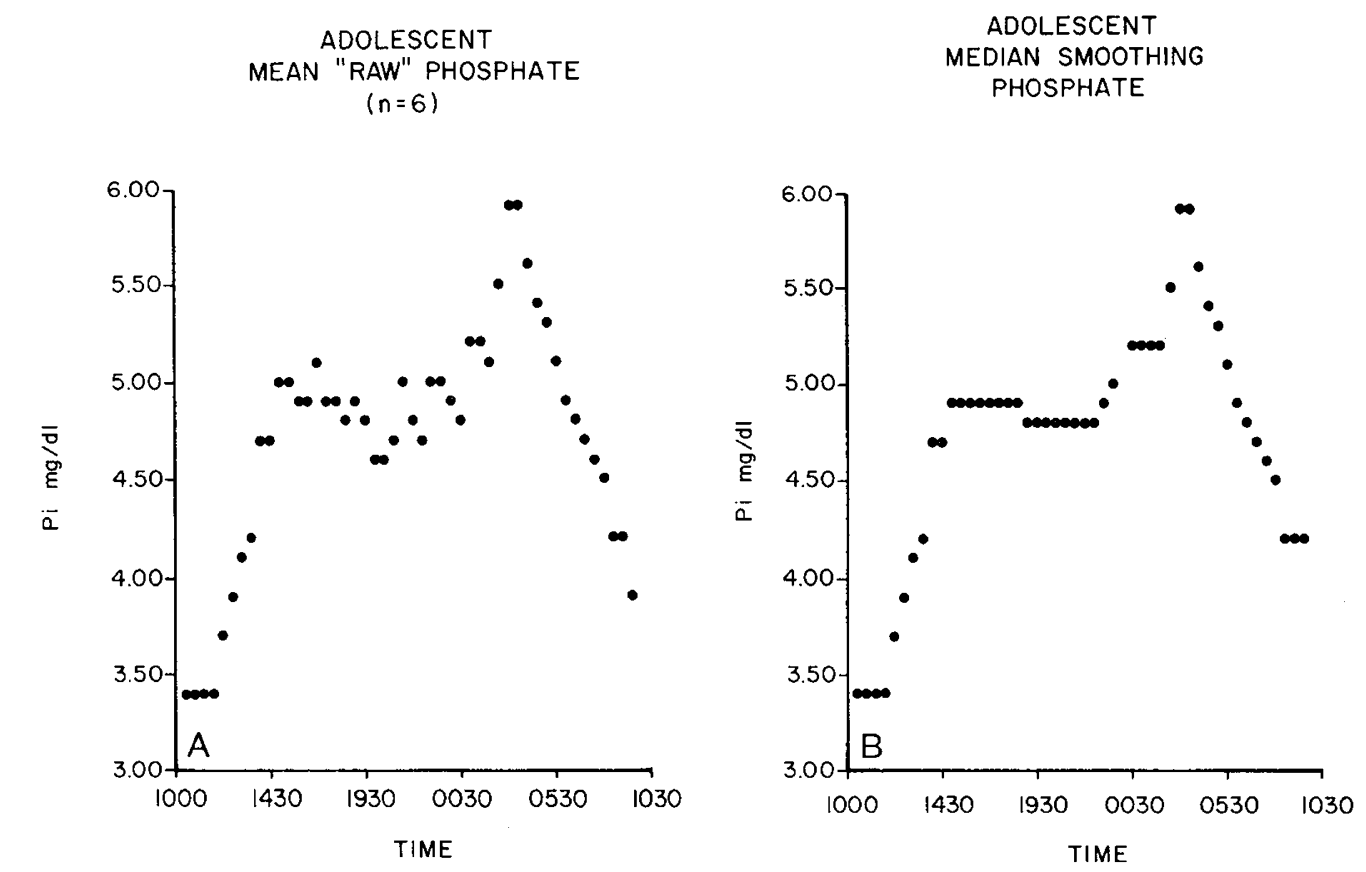

ADOLESCENT

PHOSPHATE MODEL

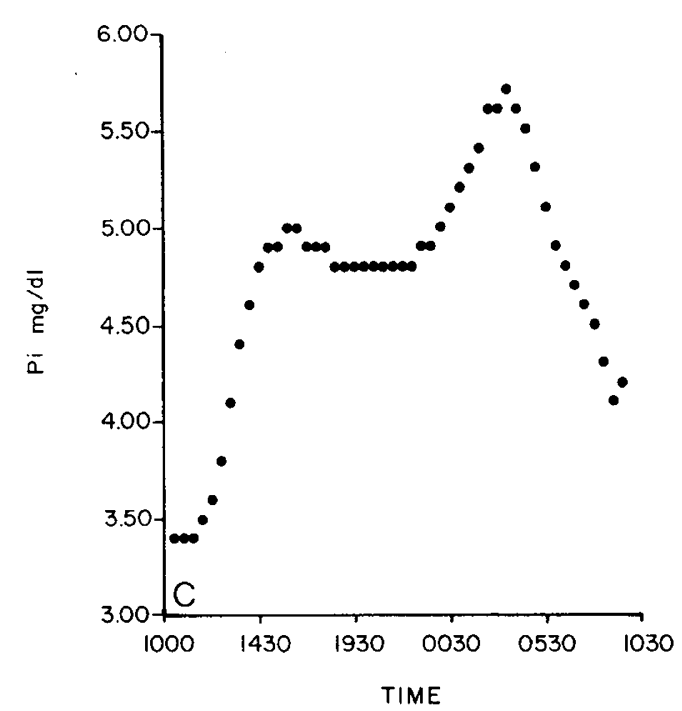

Fig. 4. As in Figure 2, Mean $P_{i}$ samples across all subjects at each time point $(A)$ were subjected to median smoothing $(B)$ and mathematical representation $(C)$.

Table 2. Linear regression and $r \rightarrow z$ transformation of individual teenagers versus mineral models*

\begin{tabular}{|c|c|c|c|c|c|c|}
\hline \multirow[b]{2}{*}{ Subject } & \multicolumn{2}{|c|}{$\mathrm{Ca}^{++}$} & \multicolumn{2}{|c|}{$\mathrm{Ca} \mathrm{a}_{\mathrm{T}}$} & \multicolumn{2}{|c|}{$P_{i}$} \\
\hline & $\mathrm{r}$ & $\mathrm{z}$ & $\mathrm{r}$ & $\mathrm{z}$ & $\mathrm{r}$ & $\mathrm{z}$ \\
\hline IB & 0.147 & 0.15 & 0.586 & 0.68 & 0.768 & 1.02 \\
\hline DY & 0.879 & 1.38 & 0.770 & 1.02 & 0.675 & 0.82 \\
\hline $\mathrm{JI}$ & 0.453 & 0.48 & 0.380 & 0.40 & 0.873 & 1.33 \\
\hline JM & 0.216 & 0.22 & 0.423 & 0.45 & 0.799 & 1.10 \\
\hline CR & 0.826 & 1.19 & 0.773 & 1.02 & 0.843 & 1.22 \\
\hline \multirow[t]{2}{*}{ DR } & 0.561 & 0.63 & 0.593 & 0.68 & 0.838 & 1.22 \\
\hline & \multicolumn{2}{|c|}{$\overline{\mathrm{Z}}=0.67(-0.30-1.66)$} & \multicolumn{2}{|c|}{$\overline{\mathrm{Z}}=0.70(0.18-1.22)$} & \multicolumn{2}{|c|}{$\overline{\mathrm{Z}}=1.11(0.75-1.47)$} \\
\hline
\end{tabular}

* Abbreviations: $\mathrm{Ca}_{\mathrm{T}}$, total calcium and $\mathrm{P}_{\mathrm{i}}$, serum phosphate. 
Table 3. Ultradian rhythms $(h)$

\begin{tabular}{lcllc}
\hline & $\begin{array}{c}\text { No. of time } \\
\text { points }\end{array}$ & \multicolumn{1}{c}{$\mathrm{Ca}^{++}$} & \multicolumn{1}{c}{$\mathrm{Ca}_{\mathrm{T}}$} & $\mathrm{P}_{\mathrm{i}}$ \\
\hline IB & 48 & $3.9,1.2$ & 11.8 & 0 \\
JI & 48 & $3.9,1.9,1.2$ & 0 & 11.8 \\
JM & 39 & $9.8,1.2$ & $6.5,2.4,1.2$ & 9.8 \\
CR & 48 & 0 & 11.8 & 0 \\
DR & 48 & 0 & $11.8,2.9,1.3$ & 11.8 \\
\hline
\end{tabular}

\section{ADOLESCENT AND ADULT} PHOSPHATE MODELS

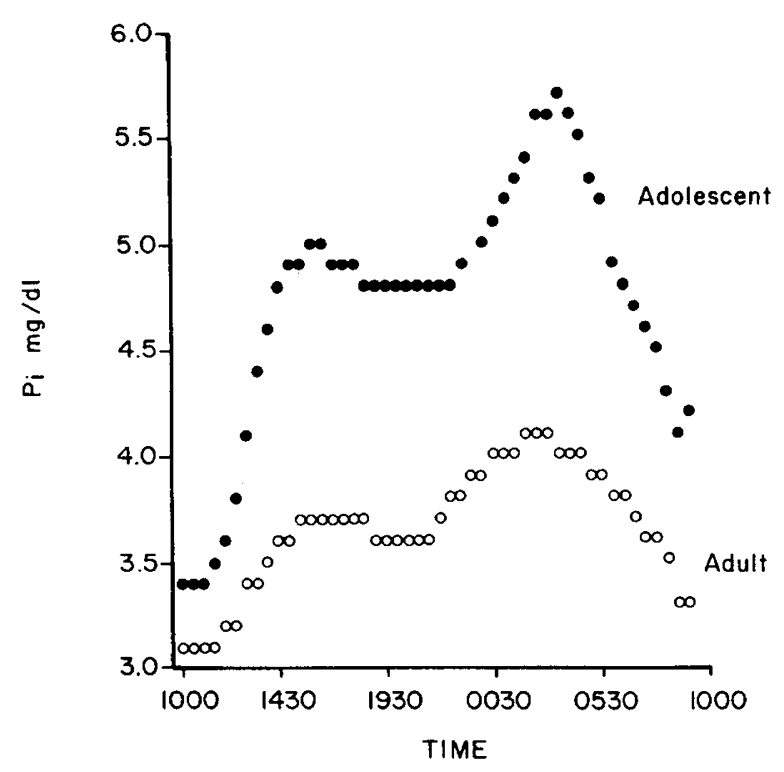

Fig. 5. Comparison of adult and adolescent circadian $P_{i}$ models.

of mineral analyses from randomly drawn blood samples (within clinical situations) may prove to be difficult, if the magnitude of these normative fluctuations is not considered.

\section{REFERENCES AND NOTES}

1. Arnaud, C. D., Tsao, H. S., and Littledike, J.: Radioimmunoassay of human parathyroid hormone in serum. J. Clin. Invest., 50: 21 (1971).

2. Avioli, L. and Teitlebaum, S.: Renal osteodystrophy. In: Edelman: Pediatric Kidney Disease. p. 336 (Little Brown, Boston, 1978).

3. Bendet, J. S. and Piersol, A. G.: Random Data Analysis and Measurement Procedures. (J. Wiley \& Sons, New York, 1971).

4. Bogden, J. D.: Blood zinc in health and disease. In: Nriagu: Zinc in the Environment. p. 137 (J. Wiley \& Sons, New York, 1980).

5. Boyar, R. M., Witkin, M., Carouth, A., and Ramsey, J.: Circadian cortisol secretory rhythms in Cushing's disease. J. Clin. Endocrinol. Metab., 48: 760 (1979).

6. Buchsbaum, M. and Harris, E. K.: Diurnal variation in serum and urine electrolytes. J. Appl. Physiol., 30: 27 (1971).

7. Carruthers, B. M., Copp, D. H., and Mclntosh, H. W.: Diurnal variation in urinary excretion of calcium and phosphate and its relation to blood levels. J. Lab. Clin. Med., 63: 959 (1964).

8. Chesney, R. W., Rosen, J. F., Hamstra, A. J., and DeLuca, H. F.: Serum 1,25dihydroxyvitamin $\mathrm{D}$ levels in normal children and vitamin $\mathrm{D}$ disorders. Am. J. Dis. Child., I34: 135 (1980).

9. Chesney, R. W., Rosen, J. F., Hamstra, A. J., Smith, C., Mahaffey, K., and DeLuca, H. F.: Absence of seasonal variation in serum concentrations of 1,25 -dihydroxyvitamin $\mathrm{D}$ despite a rise in 25 -hydroxyvitamin $\mathrm{D}$ in summer. J. Clin. Endocrinol. Metab., 53: 139 (1981).

10. Corvilain, J. and Abramow, M.: Some effects of human growth hormone on renal hemodynamics and on tubular phosphate transport in man. J. Clin. Invest., $41: 1230,1962$

11. Corvilain, J. and Abramow, M.: Growth and renal control of plasma phosphate.
J. Clin. Endocrinol. Metab., 34:452 (1972).

12. Eisenberg, E.: Effects of serum calcium level and parathyroid extract on phosphate and calcium excretion in hypoparathyroid patients. J. Clin. Invest., 44: 942 (1965).

13. Finkelstein, J. W., Roffwarg, H. P., Boyar, R. M., Kream, J., and Hellman, L.: Age related change in the 24-hour spontaneous secretion of growth hormone. J. Clin. Endocrinol. Metab., 35: 665 (1972).

14. Gertner, J. M., Horst, R. L., Broadus, A. E., Rasmussen, H., and Genel, M.: Parathyroid function and vitamin-D metabolism during human growth hormone replacement. J. Clin. Endocrinol. Metab., 49: 185 (1979).

15. Goldsmith, R. S., Richards, R., Deibe, W. J., Hulley, S. B., Holdsworth, D., and Ingbar, S. H.: Metabolic effects and mechanism of action of phosphate supplements. In: Hioco: Phosphate et Metabolisme Phosphocalcique. p. 271 (Sandoz, Paris, 1971).

16. Hall, K., Sara, V. R., Enberg, G., and Ritzen, E. M.: Somatomedins and postnatal growth. In: Rilzen and Aperia: The Biology of Normal Human Growth. p. 275 (Raven Press, New York, 1981).

17. Jubiz, W., Canterbury, J. M., Reiss, E., and Tyler, F. H.: Circadian rhythm in serum parathyroid hormone concention in human subjects: correlation with serum calcium, phosphate, albumin, and growth hormone levels. J. Clin. Invest., 51: 2040 (1972).

18. Markowitz, M. E., Rotkin, L., and Rosen, J. F.: Circadian rhythms of blood minerals in humans. Science, 213: 672 (1981).

19. Markowitz, M. E., Rosen, J. F., Smith, C. L., and DeLuca, H. F.: 24-h mineral homeostasis and sterol levels in 1,25-dihydroxyvitamin-D treated hypoparathyroid children. In: Cohn, Mathews, and Talmadge: Endocrinology of Calcium Regulating Hormones. P. 377 (Excerpta Medica, 1981).

20. Markowitz, M. E., Thorpy, M., Rosen, J. F., Laxminarajan, S., Mizruchi, M., Arnaud, S., Serata, T., and Weitzman, E. D.: Serum parathyroid hormone may undergo rhythmic changes in humans. Clin. Res., 30: 700A (1982).

21. Markowitz, M. E. Rosen, J. F. Weiss, R., Spitzer, A.. Mizruchi, M., and Arnaud, S.: 24-h patterns of blood ionized calcium, total calcium, phosphate and parathyroid hormone in adolescents with chronic renal failure. Pediatr. Res. (abstract), 4: 353A (1983).

22. Moore, M. C., Sulzman, F. M., and Fuller, C. A.: The Clocks that Time Us, Physiology of the Circadian Timing System. (Harvard University Press, Cambridge, 1982).

23. New, M. I., Schwartz, E., Parks, G. A., Landey, S., and Wiedemann, E.: Pseudohypopituitary dwarfism with normal plasma growth hormone and low serum sulfation factor. J. Pediatr., 80: 620 (1972).

24. Peraino, R. A. and Suki, W. N.: Influence of calcium on renal handling of phosphate. In: Massry and Fleisch: Renal Handling of Phosphate. p. 287 (Plenum Medical Book Co., New York and London, 1980).

25. Perry, H. M. III, Shaheb, S., Drake, D., Chappel, J., Slatapolsky, E., and Avioli, L. V.: Circadian rhythm of blood minerals in postmenopausal women. Cal. Tiss. Int. 34(suppl): S23 (1982).

26. Ritz, E., Kreusser, W., and Bommer, J.: Effects of hormones other than parathyroid hormone on renal handling of phosphate. In: Massy and Fleisch: Renal Handling of Phosphate. (Plenum Publishing Home, New York, 1980).

27. Ross, G. T., Cargille, C. M., Lipsett, M. B., Rayford, P. L., Marshall, J. R., Strott, C. A., and Rodbard, D.: Pituitary and gonadal hormones in women during spontaneous and induced ovulatory cycles. Recent Prog. Hormone Res., 26: 1 (1970).

28. Sassin, J. F., Hellman, L., and Weitzman, E. D.: Twenty-four hour growth hormone and cortisol secretion in acromegaly. Trans. Amer. Neurol. Assoc., 99: 244 (1974).

29. Shepard, R. M., Horst, R. L., Hamstra, A. J., and DeLuca, H. F.: Determination of vitamin-D and its metabolites in plasma from normal and anephric man. Biochem. J., 182: 55 (1979).

30. Sinha, T. K., Miller, S., Fleming, J., Khairi, R., Edmonson, J., Johnston, C. C. Jr., and Bell, N. H.: Demonstration of a diurnal variation in serum parathyroid hormone in primary and secondary hyperparathyroidism. J. Clin. Endocrinol. Metab., 41: 1009 (1975).

31. Thorneycroft, I. H., Misehll, D. R., Stone, S. C., Kharma, K. M., and Nakamura, R. M.: The relationship of serum 17-hydoxyprogesterone and estradiol-17 $\beta$ levels during the human menstrual cycle. Am. J. Obstet. Gynecol., 111: 947 (1971).

32 Wagner, D. R. and Weitzman, E. D.: Neuroendocrine secretion and biological rhythms in man. Psychiatr. Clin. N. Am., 3: 223 (1980).

33. Wells, M. R.: The effect of diurnal variation on total plasma calcium concentration in normal subjects. J. Clin. Pathol., 23: 772 (1970).

34. Heparin: Liquaemin Sodium Brand Heparin, Organon, W. Orange, New Jersey.

35. I MED Pump: MED Corporation, San Diego, California.

36. Deseret tubing: \#885, Deseret Company, Sandy, Utah.

37. Atomic Absorption Spectrophotometer, modified AA-6, Varian Techtron, Melbourne, Australia.

38. Autoanalyzer-Beckman Trace 3, Brea, California.

39. Nova II Ionized Calcium Analyzer, Nova Biomedical, Newton, Massachusetts.

40. Requests for reprints should be addressed to: Dr. Morri E. Markowitz, Albert Einstein College of Medicine, Montefiore Medical Center, Moses Research Building, Bronx, NY 10467 (USA).

41. This research was supported, in part, by NIH grants \#ES01060-08 and RR53.

42. Received for publication March 31, 1983.

43. Accepted for publication July 14, 1983. 